\title{
Tamm-Horsfall protein facilitates catheter associated urinary tract infection
}

\author{
Hajamohideen S Raffi', James M Bates ${ }^{1}$, Dayl J Flournoy ${ }^{2}$ and Satish Kumar ${ }^{1 *}$
}

\begin{abstract}
Background: Urinary catheters are associated, commonly with bacteriuria and frequently with urinary tract infection. Tamm-Horsfall Protein (THP) is urine's most abundant protein and is known to bind to uropathogenic bacteria. The role of THP in the pathogenesis of catheter associated urinary tract infection (CAUTI) is not clear. We examined the role of THP in facilitating bacterial binding to urinary catheters in vivo and in vitro.

Findings: Twenty one urinary catheters were obtained from 20 hospitalized patients. THP was eluted from the catheter surface and catheter segments were cultured. Additional studies were performed in vitro on unused silicone and latex catheters to determine the binding of THP, and the effect of THP on the binding of Escherichia coli (E. coli) and Pseudomonas aeruginosa (P. aeruginosa), to the catheter surface.

On catheters obtained from patients, the THP deposition was significantly more on culture positive catheters than on culture negative catheters. In the in vitro studies, THP bound to both silicone and latex catheters, and THP enhanced the adherence of E. coli and P. aeruginosa to both types of catheters.
\end{abstract}

Conclusion: THP binds to urinary catheters and facilitates the binding of uropathogenic bacteria to catheters.

Keywords: Tamm-Horsfall protein, Urinary catheters, Bacterial binding

\section{Background}

Catheter Associated Urinary Tract Infection (CAUTI) is a common hospital acquired infection. Urinary catheters are placed in one of four hospitalized patients in the United States [1]. About 26\% of catheterized patients develop asymptomatic catheter associated bacteriuria (CAB) of which $24 \%$ progress to symptomatic CAUTI [2]. CAUTI accounts for $40 \%$ of all hospital acquired infections $[3,4]$ and $80 \%$ of all hospital acquired urinary tract infections (UTI) [5]. In adult intensive care units, more than $95 \%$ of urinary tract infections are caused by urinary catheters [6].

Tamm-Horsfall protein (THP) is the most abundant protein in normal urine with multiple postulated biological functions [7-9]. THP is a glycoprotein with a variety of n-linked and o-linked glycans that give it a versatile ability to bind a variety of substances $[7,8]$. We [10] and others [11] have previously shown that THP

\footnotetext{
* Correspondence: satish-kumar@ouhsc.edu

'Department of Medicine/Nephrology, University of Oklahoma Health Sciences Center and Veterans Affairs Medical Center, 920 SL Young Blvd., WP 2250, Oklahoma City, OK 73104, USA

Full list of author information is available at the end of the article
}

plays a defensive role against UTI presumably by binding uropathogenic bacteria and helping to clear them from the urinary tract.

The role of THP as a host defense factor against UTI has not been studied in the presence of an in-dwelling urinary catheter. The abundance of THP in urine and its tendency to bind a variety of surfaces make it likely that it would bind to the surface of urinary catheters. We hypothesized that the presence of a catheter in the urinary tract may reverse the normal role of THP. Normally - in the absence of a catheter - THP acts as a host defense factor against UTI. The presence of a catheter, however, could allow THP to bind to the catheter surface and form a conditioning layer that could allow binding of bacteria and formation of a bacterial biofilm. Bacteria could multiply undisturbed in the biofilm [12] and be released into the urine upon reaching an adequate density, perpetuating bacterial presence in the urine.

At present, it is not known if THP sticks to urinary catheters and if it affects the binding of bacteria to the catheter surface. In the present study, we determined the effect of THP on binding of uropathogenic bacteria 
in vivo and in vitro to commonly used urinary catheters in the United States. Urinary catheters collected from patients were examined for THP and bacterial adherence. In the in vitro studies, silicone and latex catheters were examined for adsorption of THP and the effect of THP on the adherence of two types of uropathogenic bacteria to the catheter surface.

\section{Methods}

\section{Human studies}

Twenty one urinary catheters (17 latex and 4 silicone) were collected aseptically from 20 patients after approval from the institutional review board of The University of Oklahoma Health Sciences Center, Oklahoma City, OK. The catheter insertion and removal was performed as considered necessary for the routine clinical care by the treating physicians. The catheters were cut into $1 \mathrm{~cm}$ segments starting at the catheter tip. One segment was used for quantitation of THP binding and another for bacterial culture. Bacteria were dislodged from the catheter section by sonication and cultured on blood and MacConkey agars. Bacterial isolates were speciated with the Vitek 2 System (bioMerieux, Inc., Durham, NC) using colorimetric technology. THP was eluted from catheter segments by incubation in TEA buffer $(0.5 \%$ Triton-X 100/20 mM EDTA/pH 7.5) and quantitated by ELISA.

\section{In-vitro studies}

Human urine was collected in a sterile container and tested for sterility on MacConkey agar. One half of the urine specimen was filtered through a $0.2 \mu$ filtration unit (Nalgene, Rochester, NY) to remove THP. The whole and filtered urine specimens were analyzed for THP by ELISA and polyacrylamide gel electrophoresis followed by silver staining and Western Blot.

\section{THP binding experiments}

Bardex Infection Control (latex) and Lubri-Sil Infection Control (silicone), 20 French catheters were cut into 1$\mathrm{cm}$ segments. The catheter segments were incubated in $40 \mathrm{ml}$ of whole or filtered urine, in $50 \mathrm{ml}$ sterile conical centrifuge tubes. The tubes were rotated at $37^{\circ} \mathrm{C}$ and the solutions were changed daily. Three catheter segments were removed at 9, 12 and $24 \mathrm{hrs}$ and on days 7,14 and 30 , and rinsed in phosphate buffered saline (PBS). THP bound to the catheter segments was extracted in TEA buffer and quantitated by ELISA.

\section{Bacterial adherence experiments}

Escherichia coli (E. coli) strain UTI89 (a clinical cystitis strain mainly expressing type 1 fimbriae) and Pseudomonas aeruginosa ( $P$. aeruginosa, American Type Culture Collection \# 27314) were grown in Tryptose Broth and Brain Heart Infusion Broth, respectively. The concentration of E.coli in the broth was measured by culture of serial dilutions of the broth on Eosin Methylene Blue (EMB) agar and that of $P$. aeruginosa on Columbia Blood Base Agar. The bacteria were grown for 24 hours at $37^{\circ} \mathrm{C}$ with $5 \mathrm{uCi} / \mathrm{ml}$ of methyl- ${ }^{3} \mathrm{H}$ Thymidine $(64 \mathrm{Ci} /$ mmol specific activity). The radiolabeled bacteria were washed in Dulbecco's phosphate buffered saline (DPBS) and resuspended at a concentration of $1 \times 10^{8} \mathrm{CFU} / \mathrm{ml}$, in artificial urine [13] or artificial urine with $0.1 \mathrm{mg} / \mathrm{ml}$ THP. The bacterial solutions were incubated with $1-\mathrm{cm}$ sections of the latex and silicone catheters at $37^{\circ} \mathrm{C}$. Three sections were removed from each tube at 1, 6 and $24 \mathrm{hrs}$, and washed with DPBS. Bacterial binding to the catheter segments was measured by scintillation counting. On days 2, 4 and 7, three sections were removed from each tube, and sonicated in DPBS to dislodge the bacteria. The bacteria were quantitated by culture of serial dilutions on agar.

\section{Statistical analysis}

The data were expressed as the mean \pm SE and compared statistically using Student's t-test. Statistical significance was set at $\mathrm{P}<0.05$.

\section{Findings}

\section{Human studies}

Cultures of catheter segments were positive in 16 (15 latex and 1 silicone) and negative in 5 (2 latex and 3 silicone) catheters. The organisms isolated and the number of culture positive catheters were: Escherichia coli, 3; Enterococcus fecium, 3; Enterococcus faecalis, 5; Staphylococcus epidermidis, 4; Candida albicans, 1; Staphylococcus hominis, 1; Klebsiella pneumoniae, 1; Staphylococcus aureus, 1; Enterobacter sakazakii, 1 and Staphylococcus warneri, 1; some catheters had multiple organisms. The THP deposition was significantly more on culture positive catheters than on culture negative catheters $(8990 \mathrm{ng} \mathrm{THP} / \mathrm{cm} \pm$ 4301 vs. $865 \mathrm{ng} \mathrm{THP} / \mathrm{cm} \pm 513$, respectively; $\mathrm{P}=0.039$ ) (Figure 1).

\section{In-vitro studies}

Both silicone and latex urinary catheters were quickly and equally coated with THP from the first time point at $9 \mathrm{hrs}$ (silicone, $370 \mathrm{ng} / \mathrm{cm} \pm 65$ and latex, $456 \mathrm{ng} / \mathrm{cm} \pm$ 155). At later time points, more THP was found bound to the silicone catheters than to the latex catheters respectively: $12 \mathrm{hr}(142 \mathrm{ng} / \mathrm{cm} \pm 15$ vs $46 \mathrm{ng} / \mathrm{cm} \pm 37$, $\mathrm{P}=0.001)$, day 1 (120 ng/cm \pm 4 vs $37 \mathrm{ng} / \mathrm{cm} \pm 5$, $\mathrm{P}=0.00001)$, day $7(160 \mathrm{ng} / \mathrm{cm} \pm 33$ vs $26 \pm 5 \mathrm{ng} / \mathrm{cm} \pm$, $\mathrm{P}=0.003)$, day $14(275 \mathrm{ng} / \mathrm{cm} \pm 41$ vs $84 \mathrm{ng} / \mathrm{cm} \pm 4$, $\mathrm{P}=0.002)$ and day $30(107 \mathrm{ng} / \mathrm{cm} \pm 32 \mathrm{vs} 15 \mathrm{ng} / \mathrm{cm} \pm 5$, $\mathrm{P}=0.014)$. THP binding to urinary catheters increased further after 7 days of incubation (Figure 2). 


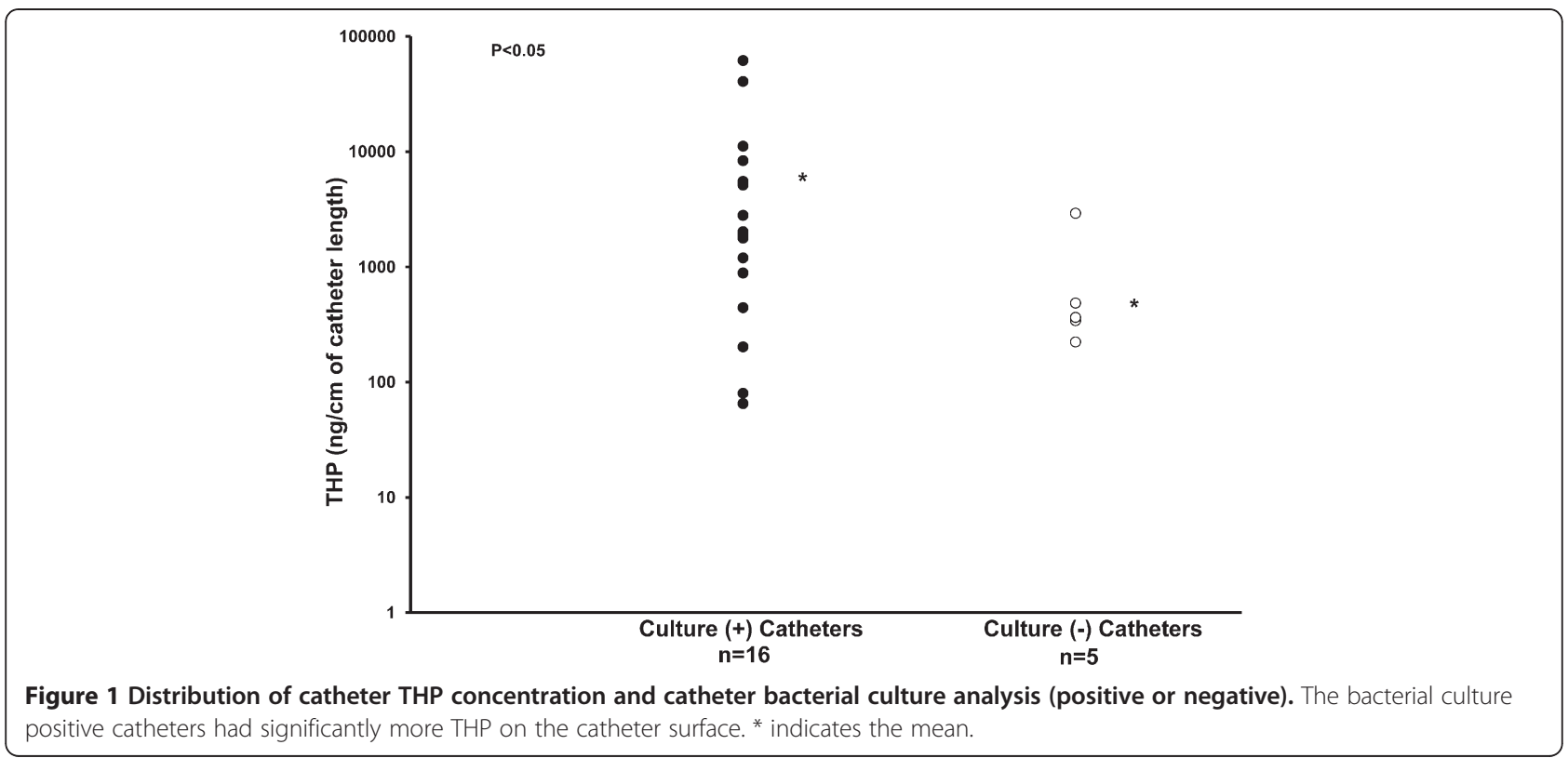

E. coli adherence (expressed as Log CFU/cm catheter), in the artificial urine with THP versus artificial urine without THP was greater to the silicone catheter at $1 \mathrm{hr}$ $(6.25 \pm 0.17$ vs $5.73 \pm 0.07, \mathrm{P}=0.02), 6 \mathrm{hr}(6.08 \pm 0.04 \mathrm{vs}$ $5.67 \pm 0.13, \mathrm{P}=0.02)$, day $1(6.1 \pm 0.02$ vs $5 . \overline{57} \pm 0.02$, $\mathrm{P}=0.00004)$ and day $7(4.2 \pm 0.2$ vs $2.9 \pm 0.2, \mathrm{P}=\overline{0} .005)$ and to the latex catheter at $6 \mathrm{hr}(5.95 \pm 0.06 \mathrm{vs}$ $5.68 \pm 0.05, P=0.01)$ than in artificial urine alone. $P$. aeruginosa adherence was more to the latex catheter at 2 days $(6.7 \pm 0.03$ vs $6.4 \pm 0.01, P=0.0003)$, and to the silicone catheter at 7 days $(4.0 \pm 0.2$ vs $2.8 \pm 0.4, \mathrm{P}=0.03)$

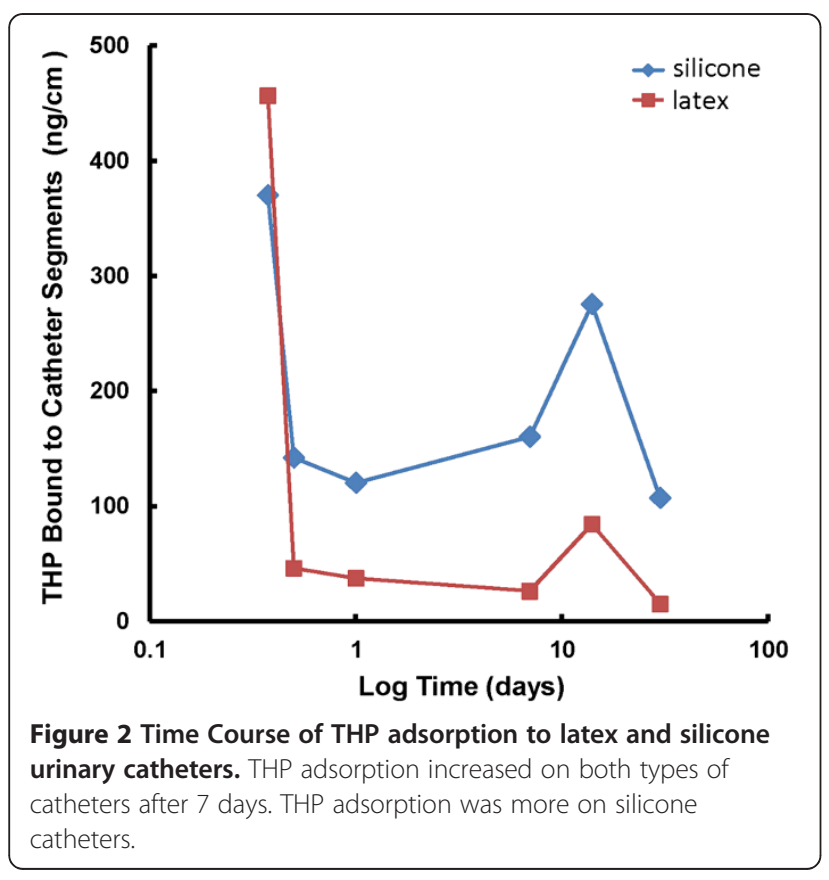

in the artificial urine with THP versus the artificial urine alone.

\section{Discussion}

The urinary tract is normally sterile. Insertion of a bladder catheter invades this sterile space and provides an opportunity for infection. E.coli accounts for about 25$50 \%$ of the cases of CAUTI. Other species isolated frequently are Proteus, Klebsiella, Enterococcus, Pseudomonas and Staphylococcus [14,15]. These bacteria are normally resident in the colon and frequently colonize the periurethral space. They ascend up the catheters into the urinary bladder on the external surface of the catheter in $66 \%$ and on the lumen of the catheter in $34 \%$ of the cases [16]. For CAUTI to occur, the bacteria need to adhere to the catheter, have an opportunity to multiply, evade normal urinary defense factors and invade the bladder epithelium.

THP has long been postulated to play a role in binding free floating (planktonic) bacteria in the urine and in aiding their excretion to help maintain the sterility of the urinary tract [17]. In vitro studies have demonstrated binding between $E$. coli and THP that was mediated by the binding of type 1 fimbriae on the surface of $E$. coli to the high-mannose structure present on THP [18]. The role of THP as a urinary defense factor was highlighted when we and others created THP gene knockout mice and demonstrated that THP-deficient mice had difficulty clearing E. coli from the urinary tract $[10,11]$. Subsequently, we extended these findings to include other uropathogenic bacteria such as Klebsiella pneumonia, Staphylococcus saprophyticus, [19] and Proteus mirabilis [20]. In a study examining 51 long term catheterized 
patients, the bacterial isolates from UTI episodes longer than 2 weeks expressed type 1 fimbriae more frequently and bound more THP than bacterial isolates from UTI episodes lasting 1 week or less [21]. These data suggested that binding between type 1 fimbriae and THP could have contributed to the persistence of CAUTI.

In our clinical study, all catheters were found to be coated with THP and the amount of THP adsorbed was higher on culture positive catheters. In our in vitro studies, THP bound to both latex and silicone urinary catheters and facilitated the binding of $E$. coli and $P$. aeruginosa to both types of catheters. THP binding to urinary catheters increased after 7 days.

These data suggest that THP which serves as a host defense factor against UTI in the absence of an indwelling urinary catheter may have the opposite effect of promoting bacterial presence in urine in the presence of a urinary catheter and that catheter removal or change at 7 days may help prevent CAUTI. The major limitation of this study is the small sample size. These data need to be confirmed in larger studies before routine change of catheters at 7 days can be recommended as a practice guideline.

\section{Conclusion}

THP, a normal host defense factor against UTI, may have a paradoxical effect of promoting UTI in the presence of indwelling urinary catheters.

\section{Competing interests}

The authors declare that we have no competing interests.

\section{Authors' contributions}

All authors made substantial intellectual contribution. HSR was involved in coordination of human studies, collection of data, interpretation and reporting of data and drafted the manuscript. JMB was involved in performing in vitro studies, collection of data from human studies, statistical analysis and interpretation of data and helped to draft manuscript. DJF was involved in bacterial identification. SK was involved in conception, design and supervision of the experiments, interpretation of results, and in preparation of the final draft. All authors read and approved the final manuscript.

\section{Acknowledgements}

Our lab obtained E. coli strain UTI89 from Dr. Scott Hultgren. Part of this work was supported by National Institutes of Health grant 1R21DK089377-01.

\section{Author details}

${ }^{1}$ Department of Medicine/Nephrology, University of Oklahoma Health Sciences Center and Veterans Affairs Medical Center, 920 SL Young Blvd., WP 2250, Oklahoma City, OK 73104, USA. ²Department of Pathology, University of Oklahoma Health Sciences Center and Veterans Affairs Medical Center, Oklahoma City, OK 73104, USA.

Received: 13 June 2012 Accepted: 17 September 2012 Published: 26 September 2012

\section{References}

1. Haley RW, Hooton TM, Culver DH, Stanley RC, Emori TG, Hardison CD, Quade D, Shachtman RH, Schaberg DR, Shah BV, Schatz GD: Nosocomial infections in U.S. hospitals, 1975-1976: estimated frequency by selected characteristics of patients. Am J Med 1981, 70:947-959.
2. Saint S: Clinical and economic consequences of nosocomial catheterrelated bacteriuria. Am J Infect Control 2000, 28:68-75.

3. Stamm WE: Catheter related urinary tract infections: epidemiology, pathogenesis and prevention. Amer J Med 1991, 91:65S-71S.

4. Stamm WE, Norrby SR: Urinary tract infections: disease panorama and challenges. J Infect Dis 2001, 183:S1-S4.

5. Hartstein Al, Garber SB, Ward TT, Jones SR, Morthland VH: Nosocomial urinary tract infection: a prospective evaluation of 108 catheterized patients. Infect Control 1981, 2:380-386.

6. Richards MJ, Edwards JR, Culver DH, Gaynes RP: Nosocomial infections in medical intensive care units in the United States. National nosocomial infections surveillance system. Crit Care Med 1999, 27:887-892.

7. Kumar S, Muchmore A: Tamm-horsfall protein-uromodulin (1950-1990). Kidney Int 1990, 37:1395-1401.

8. Serafini-Cessi F, Malagolini N, Cavallone D: Tamm-horsfall glycoprotein: biology and clinical relevance. Am J Kidney Dis 2003, 42:658-676.

9. Rampoldi L, Scolari F, Amoroso A, Ghiggeri G, Devuyst O: The rediscovery of uromodulin (Tamm-Horsfall protein): from tubulointerstitial nephropathy to chronic kidney disease. Kidney Int 2011, 80:338-347.

10. Bates JM, Raffi HM, Prasadan K, Mascarenhas R, Laszik Z, Maeda N, Hultgren SJ, Kumar S: Tamm-horsfall protein knockout mice are more prone to urinary tract infection: rapid communication. Kidney Int 2004, 65:791-797.

11. Mo L, Zhu XH, Huang HY, Shapiro E, Hasty DL, Wu XR: Ablation of the tamm-horsfall protein gene increases susceptibility of mice to bladder colonization by type 1-fimbriated Escherichia coli. Am J Physiol Renal Physiol 2004, 286:F795-F802.

12. Trautner BW, Darouiche RO: Role of biofilm in catheter-associated urinary tract infection. Am J Infect Control 2004, 32:177-183.

13. Brooks T, Keevil CW: A simple artificial urine for the growth of urinary pathogens. Lett Appl Microbiol 1997, 24:203-206.

14. Farrell DJ, Morrissey I, De Rubeis D, Robbins M, Felmingham D: A UK multicenter study of the antimicrobial susceptibility of bacterial pathogens causing urinary tract infection. J Infect 2003, 46:94-100.

15. Maki DG, Tambyah PA: Engineering out the risk for infection with urinary catheters. Emerg Infect Dis 2001, 7:342-347.

16. Tambyah PA, Halvorson KT, Maki DG: A prospective study of pathogenesis of catheter associated urinary tract infections. Mayo Clin Proc 1999, 74:131-136

17. Orskov I, Ferencz A, Orskov F: Tamm-horsfall protein or uromucoid is the normal urinary slime that traps type 1 fimbriated Escherichia coli. Lancet 1980, 1:887.

18. Pak J, Pu Y, Zhang ZT, Hasty DL, Wu XR: Tamm-horsfall protein binds to type 1 fimbriated Escherichia coli and prevents E. Coli from binding to uroplakin la and Ib receptors. J Biol Chem 2001, 276:9924-9930.

19. Raffi HS, Bates JM Jr, Laszik Z, Kumar S: Tamm-horsfall protein acts as a general host-defense factor against bacterial cystitis. Am J Nephrol 2005, 25:570-578.

20. Raffi HS, Bates JM Jr, Laszik Z, Kumar S: Tamm-horsfall protein protects against urinary tract infection by Proteus mirabilis. J Urol 2009, 181:2332-2338.

21. Mobley HL, Chippendale GR, Tenney JH, Hull RA, Warren JW: Expression of type 1 fimbriae may be required for persistence of Escherichia coli in the catheterized urinary tract. J Clin Microbiol 1987, 25:2253-2257.

\section{doi:10.1186/1756-0500-5-532}

Cite this article as: Raffi et al:: Tamm-Horsfall protein facilitates catheter associated urinary tract infection. BMC Research Notes 2012 5:532. 